\title{
Brexit or Corbyn? Campaign and Inter-election Vote Switching in the 2017 UK General Election
}

DOI:

10.2139/ssrn.3073203

\section{Document Version}

Accepted author manuscript

Link to publication record in Manchester Research Explorer

\section{Citation for published version (APA):}

Mellon, J., Evans, G., Fieldhouse, E., Green, J., \& Prosser, C. (2018). Brexit or Corbyn? Campaign and Interelection Vote Switching in the 2017 UK General Election. Parliamentary Affairs, 71(4), 719-737.

https://doi.org/10.2139/ssrn.3073203

\section{Published in:}

Parliamentary Affairs

\section{Citing this paper}

Please note that where the full-text provided on Manchester Research Explorer is the Author Accepted Manuscript or Proof version this may differ from the final Published version. If citing, it is advised that you check and use the publisher's definitive version.

\section{General rights}

Copyright and moral rights for the publications made accessible in the Research Explorer are retained by the authors and/or other copyright owners and it is a condition of accessing publications that users recognise and abide by the legal requirements associated with these rights.

\section{Takedown policy}

If you believe that this document breaches copyright please refer to the University of Manchester's Takedown Procedures [http://man.ac.uk/04Y6Bo] or contact uml.scholarlycommunications@manchester.ac.uk providing relevant details, so we can investigate your claim.

\section{OPEN ACCESS}




\author{
Brexit or Corbyn? \\ Campaign and Inter-election Vote Switching in the 2017 UK General Election \\ Jonathan Mellon \\ Geoffrey Evans \\ Edward Fieldhouse \\ Jane Green \\ Christopher Prosser \\ University of Manchester and University of Oxford
}

\begin{abstract}
The 2017 UK General Election saw the collapse of UKIP and an unusually influential campaign that saw Labour improving from a likely historic defeat to almost pulling level with the Conservatives and denying Theresa May a parliamentary majority. We argue the election should be understood in two phases: first from 2015 to the start of the election campaign, and second the campaign itself. The former period was characterised by strong switching along Brexit lines, with 2015 UKIP voters defecting heavily to the Conservatives following the outcome of the EU Referendum, which had enabled the Conservatives to make credible promises on immigration. Concurrently, many 2015 Labour supporters had defected to other parties or were undecided. The campaign then saw Labour winning voters from all sources, but particularly from previously undecided voters. While campaign vote flows were not as strongly related to Leave/Remain votes, 2015-2017 switching as a whole was heavily influenced by the EU referendum choices. We conclude 2017 was indeed a 'Brexit election', but the campaign is better understood as a general rise in support for Labour resulting from Corbyn's appeal relative to that of Theresa May, particularly among the party's own 2015 voters who had defected before the campaign.
\end{abstract}


The 2017 UK General Election came just one year after the polarizing vote to leave the European Union. The ostensible reason for calling the election was to secure an increased majority for the government's Brexit plans. ${ }^{1}$ Despite this, Brexit was barely discussed as an issue by key figures during the campaign (Snowdon 2017; Hutton 2017). Instead the discussion focused on a wide variety of other policy issues including social care, fox hunting, responses to terrorist attacks, and austerity. Rather than increase the Conservative's majority, the Conservative's majority was cut, forcing a subsequent deal with the Democratic Unionist Party.

The campaign was also remarkable because of the huge increase in support for the Labour party under Jeremy Corbyn, taking Labour from a situation where commentators questioned whether the party would survive (Walker 2017; Roberts 2016; Massie 2015) to receiving a vote share just 2.3 percentage points lower than the Conservatives, beating Labour's 2015 vote share by 9.5 percentage points. Political scientists had become accustomed to thinking campaigns rarely change the aggregate outcomes of elections (Finkel 1993). The 2017 campaign saw a surge in Labour's support, impacting significantly on the overall outcome of votes and seats. The relatively poor Conservative performance happened despite the party gaining 5.5 percentage points in vote share compared to two years earlier. The 2017 election saw a reversal of a trend towards vote fragmentation (Green and Prosser 2016), and the highest two-party vote share since 1970. Given the huge shock of Brexit and the large campaign shift, the question thus arises, was 2017 a 'Brexit election', a 'Corbyn election', or something else entirely? That is to say, did these major changes happen because of the impact of the EU referendum result a year earlier, was it due to Jeremy Corbyn's appeal, and his particular style of politics and representation (Freedman 2017), or was some other factor driving these changes?

\footnotetext{
${ }^{1}$ Announcing the election, Theresa May stated 'At this moment of enormous national significance [Brexit] there should be unity here in Westminster, but instead there is division ... Our opponents believe because the government's majority is so small, that our resolve will weaken and that they can force us to change course... If we do not hold a general election now their political game-playing will continue, and the negotiations with the European Union will reach their most difficult stage in the run-up to the next scheduled election. ...So we need a general election and we need one now...'
} 
In this paper we use the 2014-2018 British Election Study Internet Panel (BESIP) (Fieldhouse et al. 2017) to understand the sequencing of vote switching during the period from 1) the 2015 election until the start of the campaign, and 2) during the 2017 campaign itself. The results reveal that the switching between 2015 and 2017 substantially increased the relationship between EU referendum choice and Labour versus Conservative vote choice. This polarization happened prior to the election campaign, with the Conservatives disproportionately attracting Leave voters and Labour disproportionately losing Leavers. ${ }^{2}$ The campaign also saw substantial vote switching that greatly favoured Labour. Unlike switching before the campaign, Labour won voters on both sides of the EU referendum, particularly amongst those who had voted Labour in 2015 but who were undecided about their vote choice before the campaign.

Using the BES panel data - which allows us to analyse the vote intentions of the same people between 2015 and 2017 and the timing of any switches in their vote intention, we reveal that the campaign mainly determined where voters defected to, not whether they defected at all. Only $21 \%$ of voters who chose a different party in the two elections of 2015 and 2017 deserted their 2015 party during the campaign. The remainder had deserted their 2015 party earlier but had not chosen their final 2017 party before the campaign began. Analysing the 2016 EU referendum choices of these people, we find Labour was successful in drawing in both Remain and Leave voters during the campaign. So how can we reconcile the huge shifts in Labour's popularity during the campaign with the campaign's much smaller contribution to overall volatility? The key to understanding the 2017 election is that the campaign actually reduced the overall level of vote switching between 2015 and 2017 because Labour won back wavering 2015 Labour supporters in large numbers during the campaign.

\footnotetext{
${ }^{2}$ The formal election campaign happened between $18^{\text {th }}$ April 2017, when the election was called, and $8^{\text {th }}$ June 2017. Our data for the campaign period run from $5^{\text {th }}$ May 2017 (the day after the local elections) to $7^{\text {th }}$ June 2017. When we refer to the campaign in the text, we are referring to the period of time covered by the BES campaign wave starting immediately after the local elections.
} 
Far more voters switched prior to the campaign and, as mentioned above, this switching overwhelmingly happened along EU referendum lines. Following the EU Referendum decision, Theresa May made it clear during the Tory leadership contest that she would push ahead with the process of leaving the European Union: 'Brexit', as she famously - and repeatedly - pointed out, 'means Brexit'. Her agenda combined a pledge to take the UK out of the EU while clamping down on immigration. Unsurprisingly, the Conservatives consolidated the Leave vote (including $57 \%$ of all 2015 UKIP voters). Somewhat less obviously, at least before the election, was the fact the Labour party gained votes primarily from the Remain side and disproportionately lost Leave voters. Despite Labour's support for leaving the European Union and the Liberal Democrats offering the most proRemain position, Remain voters moved towards Labour in greater numbers. Labour was seen as offering a softer Brexit alternative to Theresa May's 'hard' Brexit position.

Our answer to the question of whether the 2017 election was a 'Brexit election' or a 'Corbyn election' is that the 2017 election was predominantly a Brexit election, and a Corbyn and May campaign. The EU referendum was a significant shock to an already volatile electorate which substantially reshaped the bases of political competition in just two years. However, the subsequent emphasis on leadership and more traditional Labour and Conservative competition led to a very different pattern of switching during the campaign itself. Both factors can account for the significant rise in the votes for the two-major parties, which represented a significant change from a trend towards fragmentation that had seen its high-point in the 2015 election just two years before.

\section{Data}

This paper uses the British Election Study Internet panel (Fieldhouse et al. 2017) to examine interelection vote switching (switching between the 2015 election and prior to the 2017 election campaign) and vote switching during the 2017 campaign itself. We interviewed approximately 30,000 respondents in each wave, including re-interviews with as many respondents from previous 
waves as possible. The BES internet panel (BESIP) is therefore an ideal source to examine withinperson change over this time period.

At the time of writing the BESIP survey includes 13 waves, from February 2014 to June 2017. We focus primarily on data from the 2015 post-election wave (wave 6) and subsequent waves. This includes the EU referendum pre-, campaign and post-election waves (waves 7-9) and the 2017 General Election pre, campaign and post-election waves (waves 11-13). To maintain comparability we use the wave 6 to wave 13 panel sample throughout, with the exception of the cross-sectional analysis of the wave 12 campaign data which uses the full available sample for each day. ${ }^{3}$

The BESIP campaign wave (wave 12) is a unique resource with which to explore the dynamics of the campaign. From the day after the local elections (May 5) to the day before the General Election (June 7), BESIP surveyed a randomly selected subset of the panel each day, giving a sample of around 1,000 people for every day of the campaign. These data are unrivalled for shedding light on vote switching and stability of people who previously voted in 2015 for one of the parties, and comparing those votes - and how they voted in 2017 - with their 2016 EU referendum vote choice. But we do not use the BESIP data to analyse the impact of voter turnout on the 2017 election here. For that separate analysis, the in-person BES survey and vote validation exercise would be needed, which is unavailable at the time of writing. UK turnout was $68.8 \%$ of registered voters in 2017: 2.5 percentage points higher than in 2015. Various polls indicated youth turnout (which skewed heavily towards Labour) was high compared to previous elections (Ipsos MORI 2017). However, we cannot yet analyse any potential impact of a surge in new voters towards Labour, the reasons for any surge, or the impact of any differential age basis for turnout on each party's fortunes in 2017.

We also do not analyse the situation in Scotland separately, which saw substantial volatility. The dynamics of politics in Scotland have substantially diverged from those in England and Wales and

\footnotetext{
${ }^{3}$ For weighted cell counts for each origin in each wave, see tables $\mathrm{S} 5$ and $\mathrm{S} 6$ in the supplementary material.
} 
require further study in their own right. Instead, all analysis in this paper focuses on England and Wales except where otherwise mentioned.

\section{7 in Context}

There is strong evidence that the 2017 election marks a fundamental shift in British politics. In total, 32\% of respondents voted for a different party in 2015 and 2017, a slightly lower percentage than switched between 2010 and 2015 (Mellon 2016), although 2010, 2015 and 2017 are the three highest recorded levels of volatility across all elections covered by BES panels between 1964 and 2017). More importantly, however, despite spanning only a two year period, 2015-2017 saw the highest recorded level of combined Labour-Conservative switching as a percentage of Labour and Conservative voters at the previous election (in either direction) in any British Election Study interelection panel (the full series is shown in Figure 1 ). ${ }^{4}$ Additionally, other elections that saw high levels of switching between Labour and the Conservatives took place during periods of convergence between the parties, which may have made it easier to jump the 'gap' between the two major parties. The fact that $12 \%$ of 2015 Conservative voters switched to voting for a Corbyn-led Labour party indicates a major change in the political landscape and the presence of a new issue that fundamentally altered the basis of electoral choice.

\footnotetext{
${ }^{4}$ These figures are for Britain as a whole for comparability across the whole series.
} 


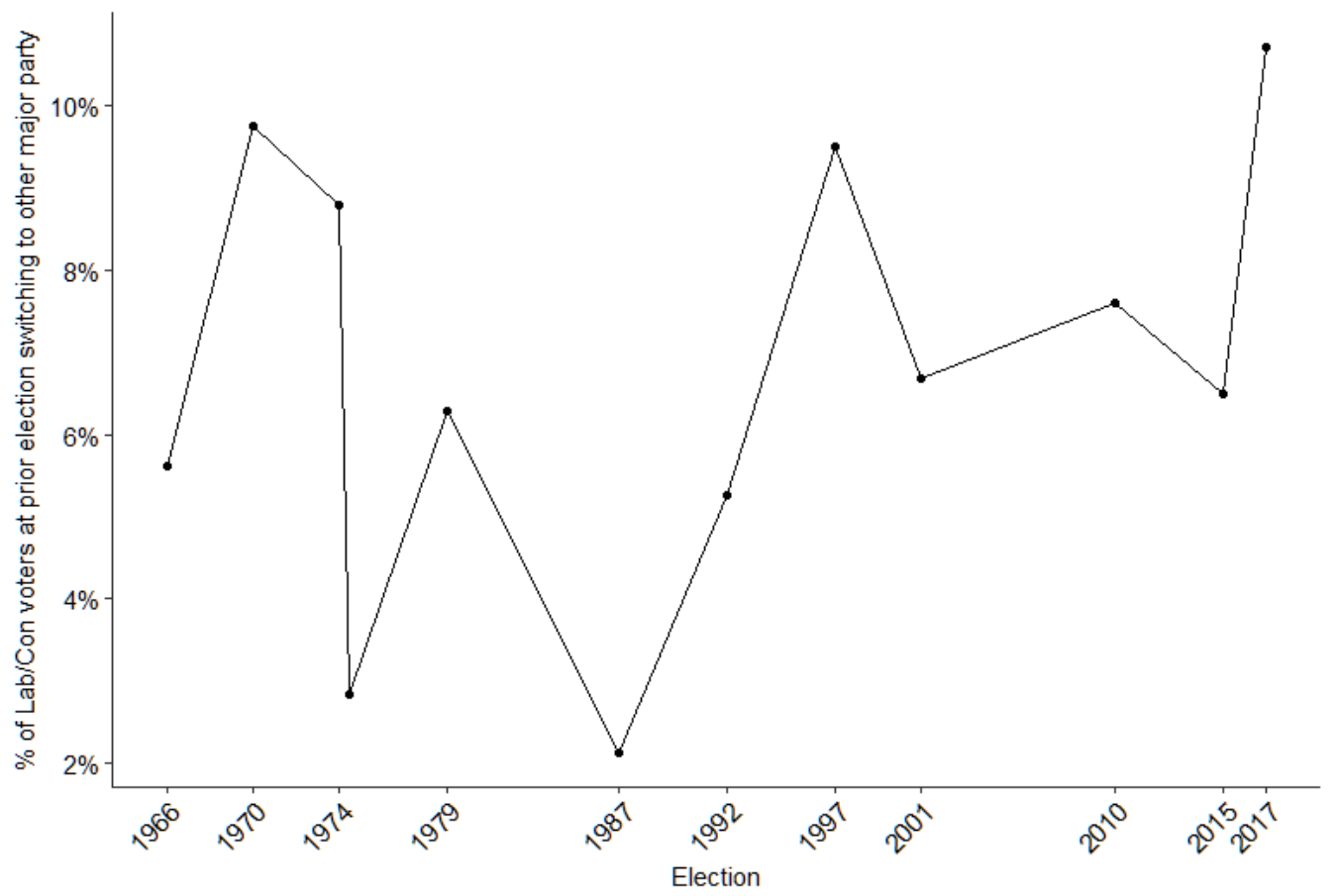

Figure 1 Combined level of switching from Labour to the Conservatives and from the Conservatives to Labour between one election and the next as a percentage of Labour and Conservative voters at the previous election. Source: British Election Study Inter-election panels 1964-2017.

\section{Two periods of switching}

To understand the 2017 election we must focus on the time at which voters switched. Overall, just $56 \%$ of BES panel respondents named the same party as: 1) their 2015 vote, 2) their vote intention prior to the 2017 campaign, and 3) their 2017 vote choice. However, only 32\% of respondents voted for a different party in 2015 and 2017. The remainder of switching within the 2015-2017 period therefore consists of $12 \%$ of all voters who intended to vote for another party before the campaign but ultimately returned to their 2015 vote choice. Switching would have been substantially higher without the impact of the 2017 election campaign reverting people back to their previous vote choice in 2015.

This switching was not evenly distributed across the parties. Table 1 shows when each party's 2017 voters switched to that party (each row sums to $100 \%$ of the party's 2017 voters). 'Loyal' voters are those who voted for the party in 2015 and intended to vote for that party at the start of the 
campaign (and who also voted for the party in 2017), returners are those who voted for the party in 2015 but did not intend to vote for the party at the start of the campaign (but who voted for the party in 2017). Campaign recruits are those who voted for a different party in 2015 and did not intend to vote for the party at the start of the campaign (but who voted for the party in 2017). Precampaign recruits are those who voted for a different party in 2015 and intended to vote for the party at the start of the campaign (and who voted for the party in 2017).

\begin{tabular}{lccccc}
\hline 2017 vote & Loyal & Returners & $\begin{array}{c}\text { Pre-campaign } \\
\text { recruits }\end{array}$ & $\begin{array}{c}\text { Campaign } \\
\text { Recruits }\end{array}$ & Total \\
\hline Conservative & 68 & 5 & 18 & 9 & 100 \\
Labour & 50 & 19 & 11 & 20 & 100 \\
& Table 1 Timing and loyalty of each party's 2017 vote (\%).
\end{tabular}

Table 1 reveals that the Conservatives did much better at retaining their 2015 voters throughout the time period, and the Conservatives also did better in gaining new supporters before the election campaign. However, Labour did much better than the Conservatives at winning back voters and winning new voters during the campaign.

Two-thirds of the Conservatives' 2017 voters were people who voted Conservative in 2015 and intended to vote Conservative before the campaign. By contrast, only half of Labour's 2017 voters supported Labour in 2015 and also did so prior to the General Election campaign. The Conservatives had already won two-thirds of their new 2017 recruits by the start of the General Election campaign (or $18 \%$ of the Conservatives' total 2017 vote), substantially more than the share Labour attracted during this period ( $11 \%$ of Labour's total 2017 vote). Labour and the Conservatives differed, however, in the portion of their 2017 support they attracted during the campaign itself $(40 \%$ of Labour's total 2017 voters compared with 14\% of the Conservatives' total 2017 voters). Labour's campaign recruitment was evenly split between recapturing its own 2015 voters who were either undecided or who intended to vote for another party before the campaign (19\% of Labour's 2017 vote share) and bringing new voters who had not intended to support Labour before the campaign or in 2015 ( $20 \%$ of Labour's 2017 vote share). Consequently, the story of the 2017 campaign is nearly 
as much about how Labour reclaimed its 2015 voters as it is about how Labour captured a new segment of the electorate.

Because of the very different patterns of switching before and during the campaign, we break the next part of our analysis of 2015-2017 vote switching down by these two periods. We also analyse the destinations of switching in the two periods by whether respondents voted leave or remain in the EU referendum. ${ }^{5}$ This allows us to evaluate how much 2017 vote choices were structured along whether voters supported Brexit or not; whether - and to what degree - the 2017 election was a 'Brexit election'.

\section{Switching before the campaign}

Figure 2 breaks down vote switching between 2015 and the start of the General Election campaign by whether people supported Leave and Remain in the referendum. Figure 2 demonstrates a clear divide in vote intentions along EU referendum lines prior to Theresa May calling the election.

Leave voters

There has been some doubt about whether former UKIP voters switched 'en bloc' to the Conservatives in the election (Mckibbin 2017). The individual level BES data demonstrate that, by the start of the campaign, 47\% of all 2015 UKIP voters had switched to the Conservatives, with just $33 \%$ still intending to vote for UKIP. UKIP has tended to lose a lot of its voters between elections, but the party had previously also been successful in replacing them (Evans and Mellon 2015). With the EU referendum, UKIP's losses were substantial, and no significant level of replacement took place.

Leave voting 2015 Labour voters also demonstrated substantial movement by the start of the 2017 campaign, with barely more than half still intending to vote Labour (51\%). The retention rate of

\footnotetext{
${ }^{5}$ For the complete transition tables broken down by Brexit vote for these two periods see tables $\mathrm{S} 1, \mathrm{~S} 2, \mathrm{~S} 3$ and S4 in the supplementary material.
} 
leave voters before the campaign was almost the same for Labour and UKIP. The Conservatives were the party that benefited most from Labour defection (gaining $16 \%$ of Labour Leavers), but an even larger proportion $(21 \%)$ stated they didn't know who they would vote for before the campaign. Although the Liberal Democrats' 2015 vote was already strongly Remain leaning (70\%), a non-trivial proportion of their 2015 electorate voted Leave. These voters defected at very high rates: only $32 \%$ stayed with the Liberal Democrats by the start of the 2017 campaign, a retention rate similar to when their vote collapsed between 2010 and 2015. Putting the flows together, the Conservatives were clearly dominant among Leave voters ( $54 \%$ of all Leave voters excluding those who did not intend to vote) by the start of the 2017 campaign. Theresa May's appeal to Leave voters seemed to be working when she called the General Election. Of course, an important shift also occurred among Remain voters, however, but the flow of Remain votes was not as clear as the flow for Leave.

\section{Remain voters}

Many 2015 Labour (11\%) and Conservative (12\%) voters were undecided on the Remain side prior to the 2017 campaign. Despite campaigning to become the 'party of Remain', the Liberal Democrats made relatively little progress in consolidating the Remain vote. While the Liberal Democrats' recruited $13 \%$ of 2015 Labour and 11\% of 2015 Conservative Remain voters this was partially offset by the loss of $40 \%$ their own 2015 Remain voters. Combined with the Liberal Democrats' loss of Leave voters, the party's overall share increased by only 2 percentage points since 2015 by the start of the campaign. Whilst Labour retained a greater proportion of Remain voters than Leave voters prior to the campaign, the one group both Labour and the Liberal Democrats were highly successful in recruiting were 2015 Green Remain voters. $42 \%$ of 2015 Green voters switched to Labour and 15\% of switched to the Liberal Democrats, though the Green share was of relatively small in 2015. This success may reflect Jeremy Corbyn's already well-established appeal among more liberal young voters who had been disproportionately likely to vote Green in 2015. 
Overall, the picture appears to be that the Conservatives made a compelling appeal to Leave voters between 2015 and the start of the 2017 General Election campaign. While the largest section of new support derived from UKIP, the Conservatives picked up substantial numbers of Leave voters from all 2015 origins, including Labour. This broad recruitment suggests the movement on the Leave side represented genuine realignment around the EU referendum issue rather than a simple consequence of UKIP's implosion. Although Labour did not succeed in consolidating Remain voters in the same way as the Conservatives (possibly due to elite divisions within the Labour party and the fact the Liberal Democrats were also competing for voters who had supported Remain), it lost a larger proportion of Leave voters which left Labour with a considerably more Remain-leaning support base by the start of the campaign. 


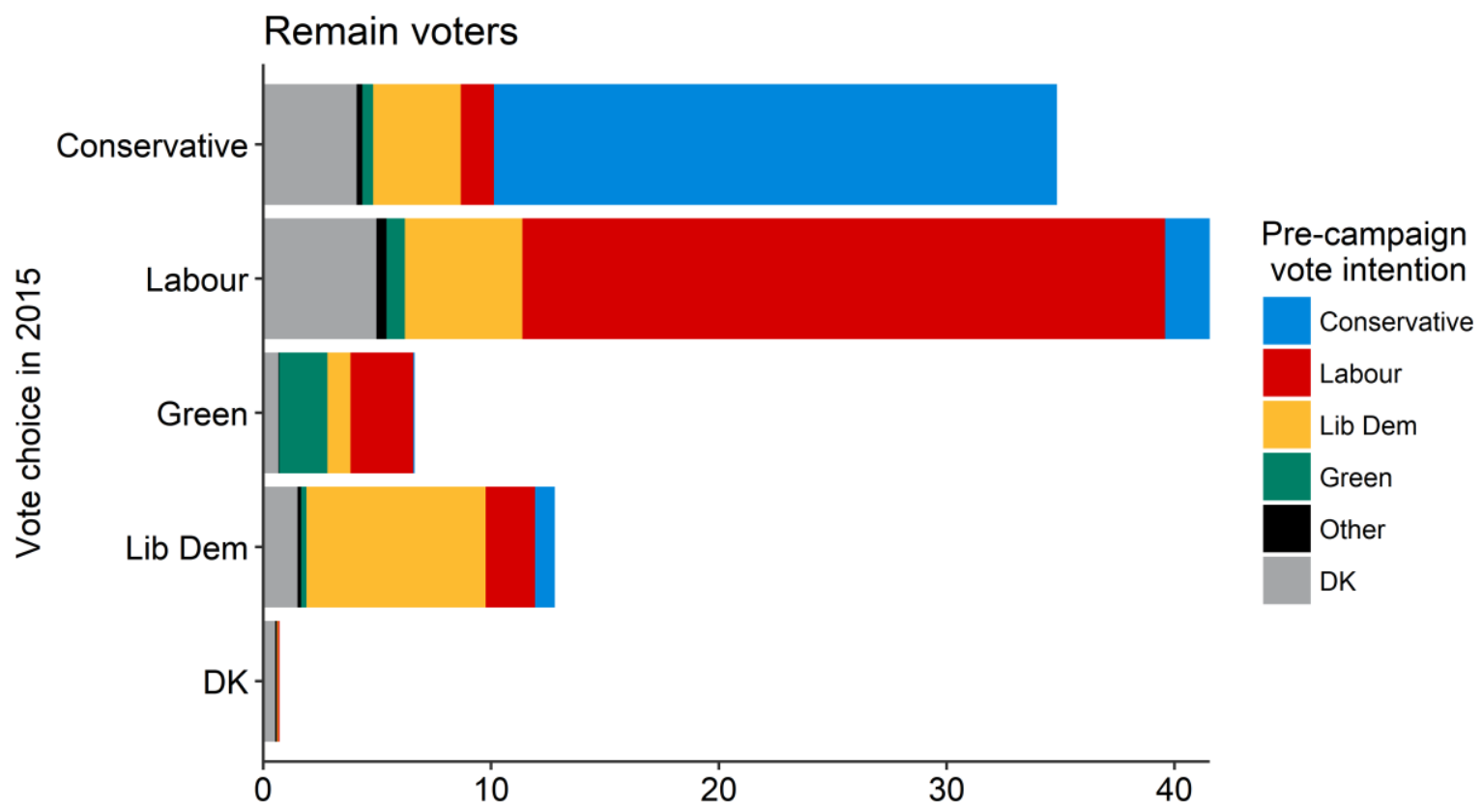

$\%$ of all remain voters who intend to vote for party prior to 2017 campaign

\section{Leave voters}

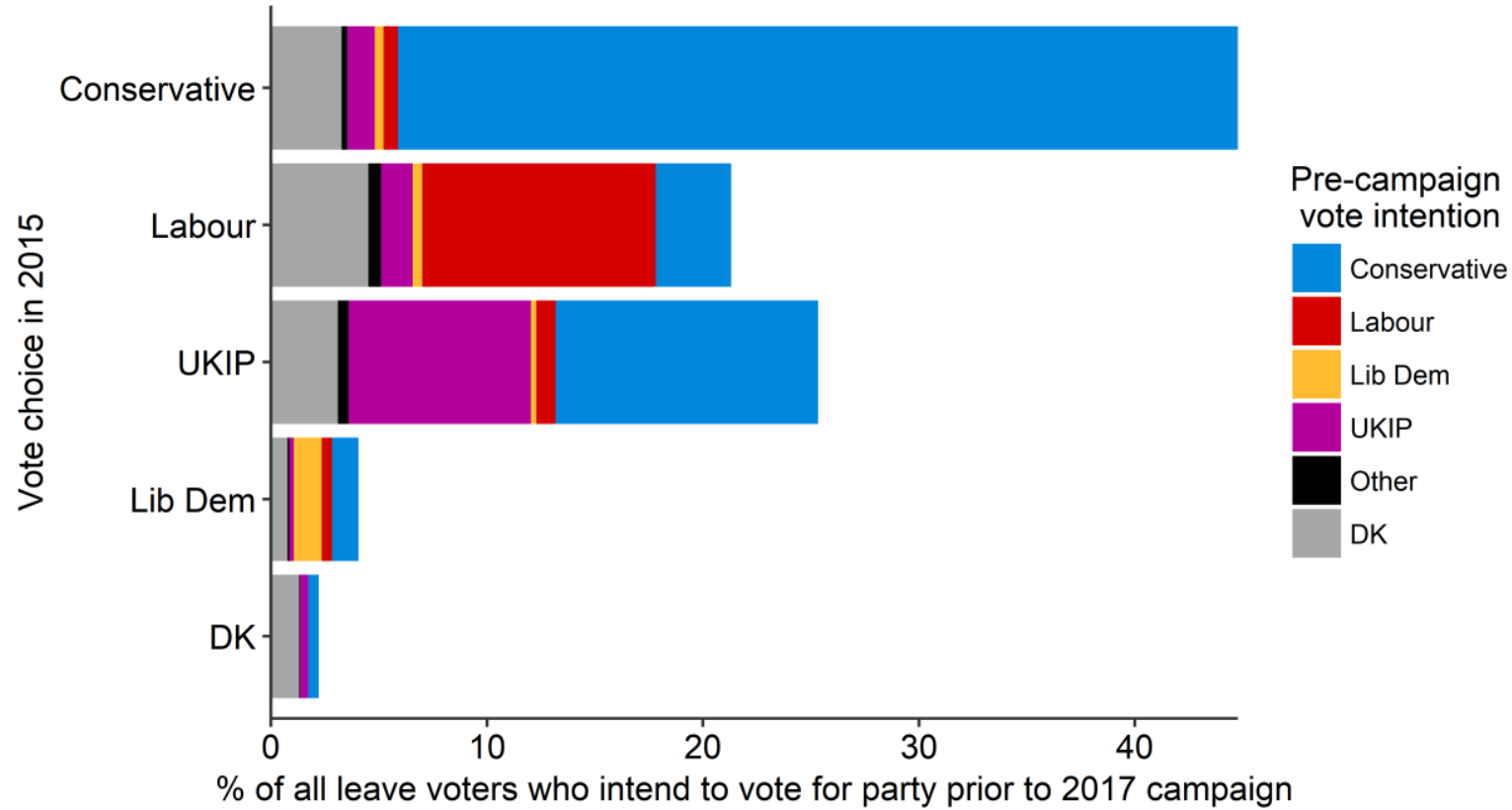

Figure 22015 General Election to 2017 pre-campaign wave switching for Leave and Remain voters. Each bar represents the percentage of all Leave or Remain voters that to voted for a particular party in 2015 and the sections of those bars show the party they intended to vote for immediately prior to the 2017 campaign. The bars on each chart sum to $100 \%$ when combined with the omitted origins (e.g. Plaid Cymru).

\section{Campaign}


The 2017 campaign appears unusually volatile at first glance, reflecting the largest change in vote shares for the two major parties in a campaign since 1945. However, this is only true at the aggregate level. At the individual level the amount of campaign switching between parties in 2017 (19\%) was only slightly higher than 2015 (17\%) and lower than 2010 (22\%). If we include respondents who were undecided before the start of the campaign, switching was somewhat higher in 2017 (30\%) than 2015 (24\%) or 2010 (28\%). Overall, however, the 2017 election campaign was not exceptionally volatile. The important difference in 2017 was that the flow was overwhelmingly in one direction. In 2015, the Conservatives won just 7 percentages points more late switching voters than Labour,-meaning the switchers mostly cancelled each other out. In 2017, however, Labour won $54 \%$ of switchers, compared to $22 \%$ for the Conservatives (a 33 percentage point lead). This was partially driven by Labour winning more than half of those who were undecided before the campaign started in 2017.

Figure 3 shows the flow of the votes between the start and end of the 2017 campaign broken down by Leave and Remain voters as before. While there was some difference between Leave and Remain voters in terms of vote flows during the campaign, these differences were much less pronounced than before the campaign. 


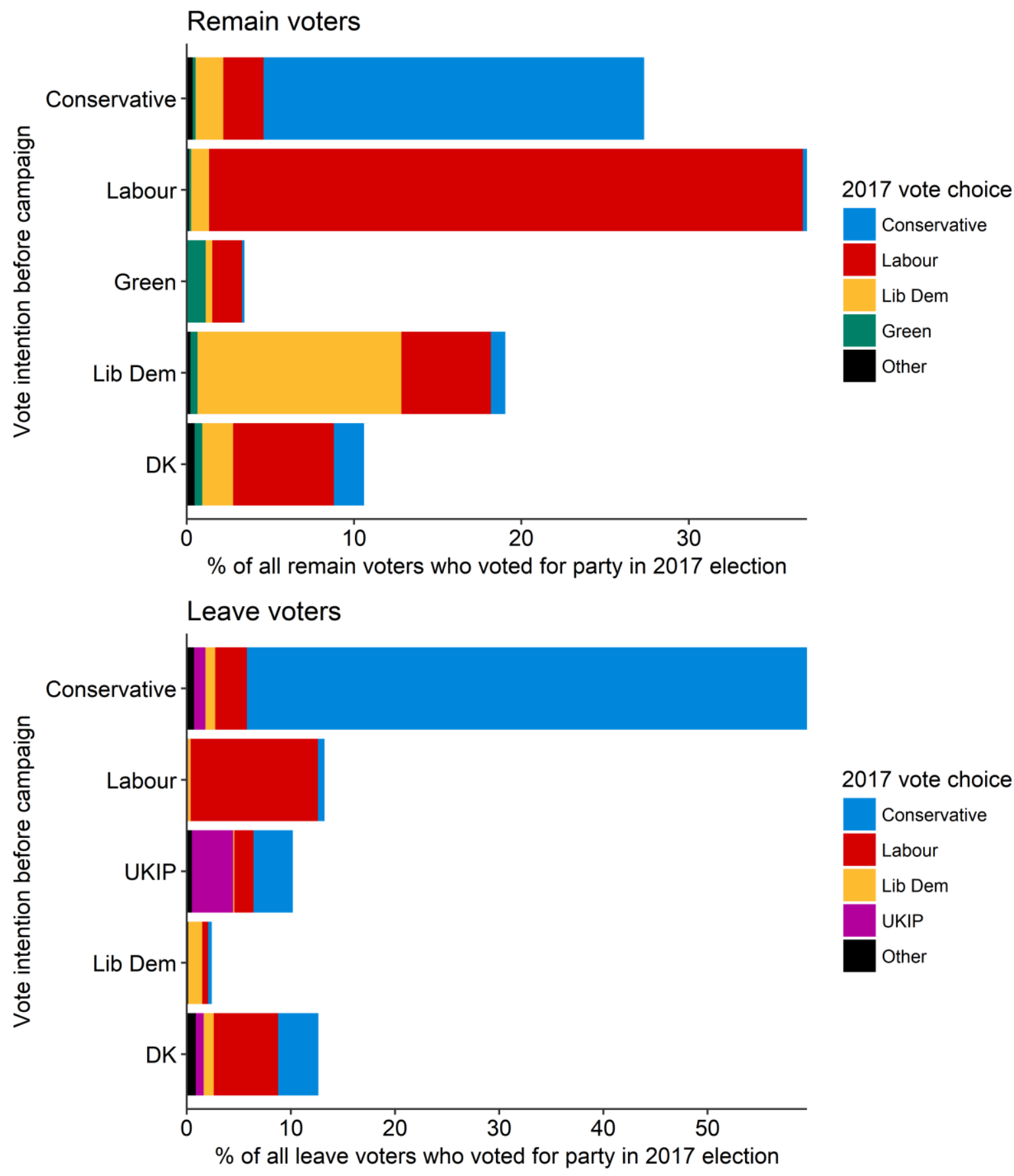

Figure 32017 Pre-campaign to 2017 General Election vote switching. Each bar represents the percentage of all Leave or Remain voters that intended to vote for a particular party before the start of the 2017 campaign and the sections of those bars show the party they ultimately voted for. The bars on each chart sum to $100 \%$ when combined with the omitted origins (e.g. Plaid Cymru).

Figure 3 shows Labour's largest source of votes in the campaign was from respondents who said they were undecided beforehand. Labour attracted substantial numbers of undecided voters on the 
Leave side (52\% switched to Labour) and the Remain side (57\% switched to Labour). On the Leave side Labour also successfully attracted the votes of $21 \%$ of UKIP intenders and $6 \%$ of Conservative voters. This was a substantial change from before the campaign when Labour had only attracted $4 \%$ of 2015 UKIP and $2 \%$ of Conservative 2015 Leave voters. In the case of UKIP, the campaign loss to Labour was still numerically small because of the large proportion of voters UKIP had already lost prior to the start of the campaign.

The Conservatives continued to take large chunks of the residual UKIP vote during the campaign (36\% of pre-campaign UKIP intenders) as well as $27 \%$ of Leave voters who were undecided before the campaign began. However, these flows were much smaller than the total flow of votes to Labour and were counteracted by Conservative defections to Labour during the campaign ( $11 \%$ of Remain voting and $6 \%$ of Leave voting Conservative intenders switched to Labour during the campaign). Overall, the cumulative effect of the pre-election and campaign switching meant Labour ended up winning $53 \%$ of all Remainers and the Conservatives $59 \%$ of Leavers.

What factors might account for these campaign flows asides from Brexit preferences? Probably the most dramatic change during the campaign was the shift in respondents' perceptions of Theresa May and Jeremy Corbyn. Figure 4 shows the average ratings on a 0-10 like scale for May and Corbyn across each day of the campaign using the daily BES data from wave 12. The trends show May's ratings precipitously declining throughout the campaign with Corbyn's rising commensurately. By the end of the campaign the two leaders were rated almost equally. 


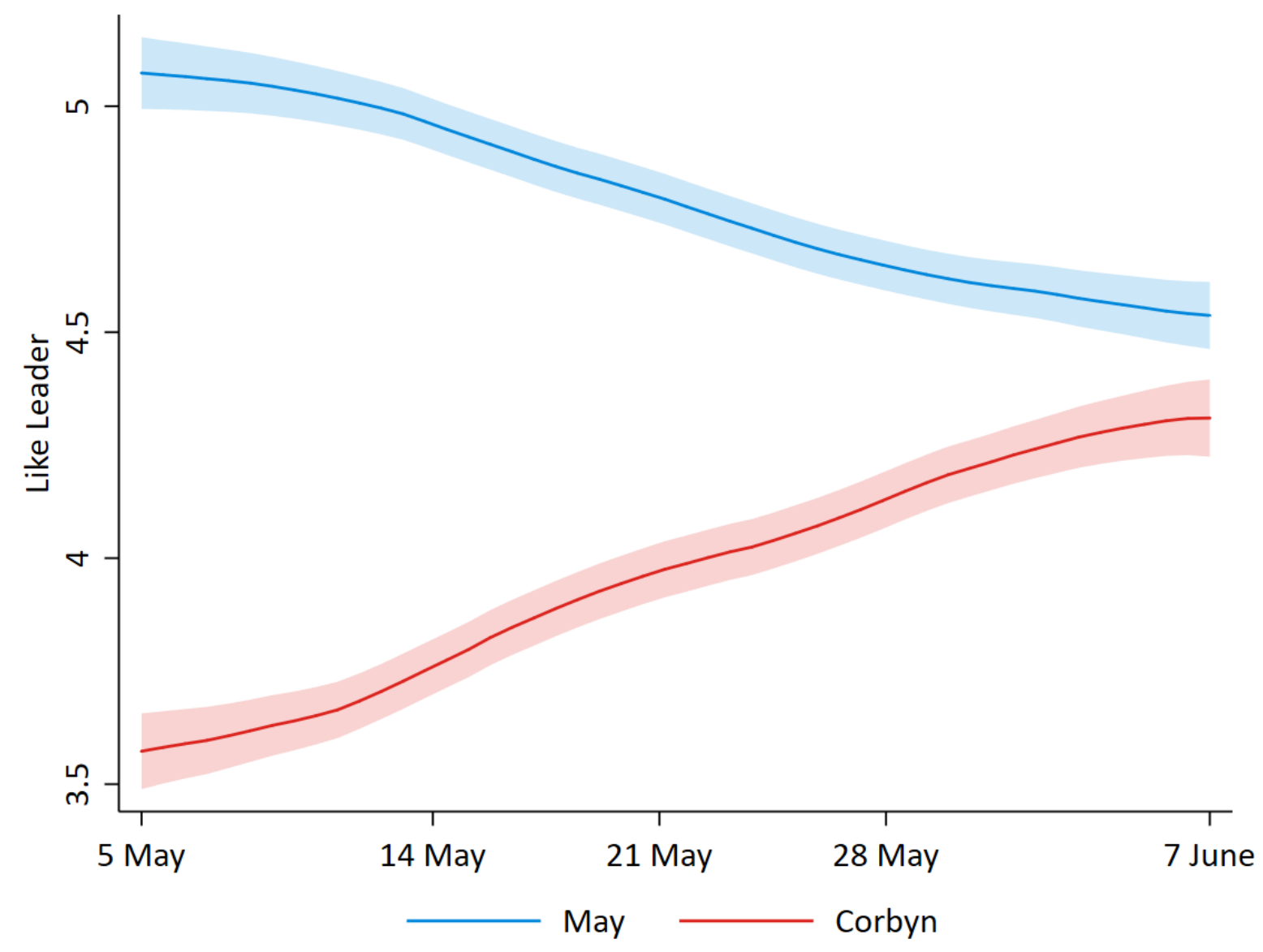

Figure 4 Leader like ratings over the campaign. The lines show the smoothed mean rating and the shaded areas give 95\% confidence intervals for the smoothed mean. Based on 30,151 English and Welsh respondents to the wave 12 daily campaign survey.

We cannot say for sure whether Theresa May's appeal was stronger in pushing voters towards Labour, or whether Jeremy Corbyn's appeal was stronger in pulling previously undecided Labour voters back to Labour as well as voters from other parties. However, while Brexit continued to structure the vote during the campaign at the margins, a significant change during the campaign was the support for each of the leaders. In the case of Labour, the increase in Corbyn's popularity appears to have minimized the amount of switching between 2015 and 2017 by reassuring previous Labour voters, and retaining votes won by Labour prior to the campaign. Changes in respondents' assessments of both May and Corbyn were strongly associated with switching to Labour during the campaign (Figure 5). Figure 5 presents the percentage of respondents who did not intend to vote 
Labour before the campaign who voted Labour in 2017 according to how their ratings of Theresa May or Jeremy Corbyn changed between the pre-campaign and post-election waves of the BESIP.

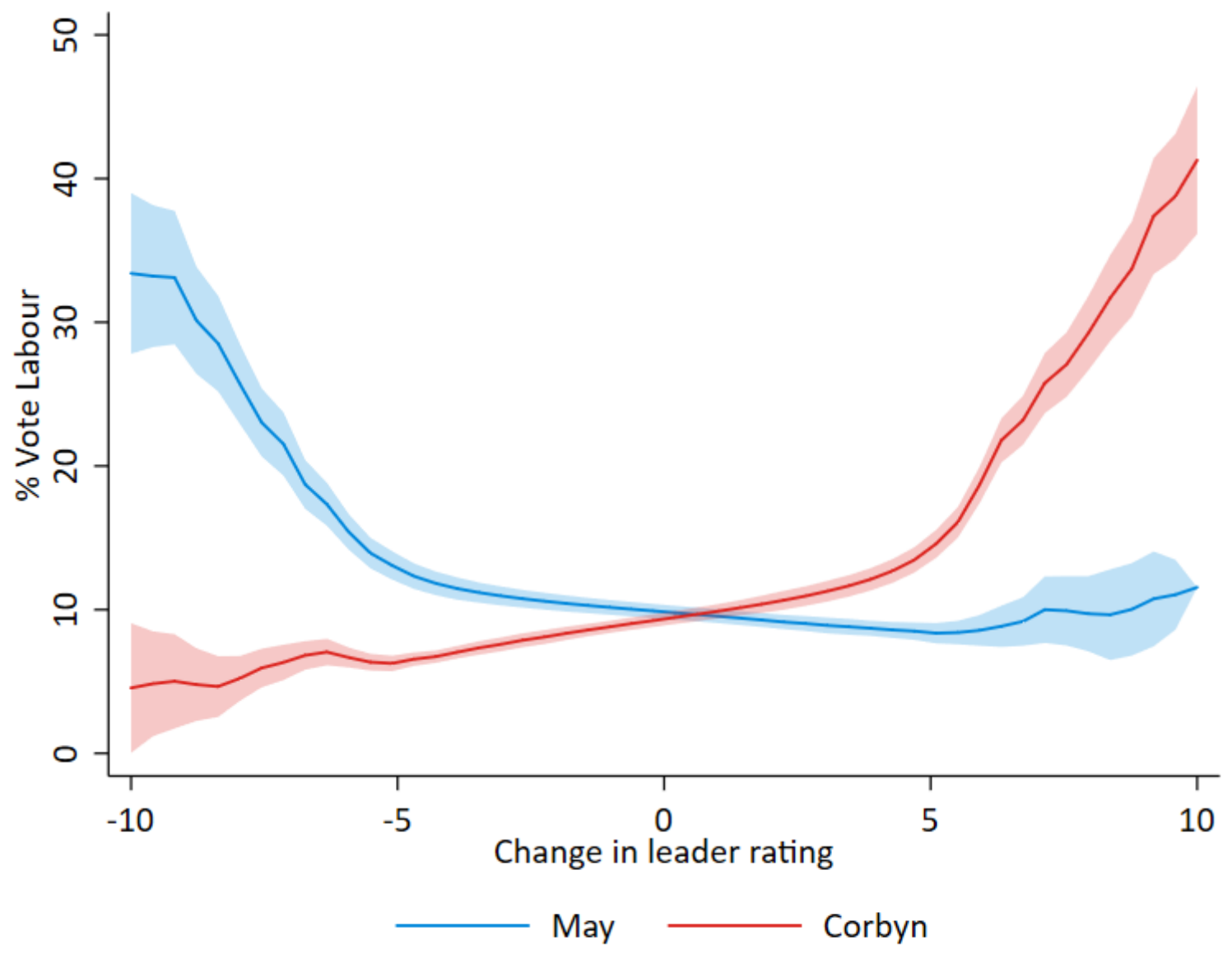

Figure 5 Probability of voting Labour in 2017 for respondents who did not intend to vote Labour prior to the campaign. Smoothed means (bandwidth 2.75) and 95\% confidence intervals shown. Wave 11-13 panel weights used (weighted $n=14,423)$.

The extent of 2017 campaign switching strongly contrasts with the campaign effects literature. The consensus has generally seen campaigns as having relatively small impacts on voters in most cases (Finkel 1993), with elections being highly predictable months ahead of time (Erikson and Wlezien 2012; Finkel 1993) (although some studies have identified larger effects in certain cases (Rudiger and Farrell 2002; lyengar and Simon 2000)). Although, as Erikson and Wlezien (2012) point out the net effect of campaigns has always varied according to the political context, with late events occasionally having a substantial impact, a move of this size in one direction sits uneasily with the idea that campaigns simply cancel out or move towards the fundamentals. 


\section{Was 2017 really a Brexit realignment?}

On the basis of aggregate constituency results, there has been some debate about whether the 2017 General Election constitutes a Brexit realignment (Heath and Goodwin 2017; Jennings and Stoker 2017). In particular, Jennings and Stoker (Jennings and Stoker 2017) argue the 2017 General Election was not a Brexit realignment election but instead "a symptom of a longer-term divide that is emerging between citizens residing in locations strongly connected to global growth and those who are not". We suggest such an entrenchment can signify and lead to a Brexit realignment when parties compete and attract votes on the basis of an issue such as Brexit that taps into liberalauthoritarian issues such as immigration (Evans and Mellon 2017a). Brexit does indeed reflect a cosmopolitan divide in British politics, but individual level BES data shows such a divide in voting patterns is apparent not just between more or less cosmopolitan areas, but between Leavers and Remainers across all parts of the country. ${ }^{6}$ Additionally, the individual level data make it clear the 2017 election saw a structural change in the way this divide translates onto the British party system. Prior to the EU referendum, divisions over cosmopolitan issues such as European integration and attitudes towards immigration cut across the traditional Labour-Conservative divide in British politics and helped to drive the fragmentation of the British party system (Fieldhouse et al. 2018). The result of the referendum, and the subsequent move of the Conservative party to present itself as the 'party of Brexit', reversed the trend towards party system fragmentation. Instead, the cosmopolitan divide now drives the concentration of the party system and the rise in two-party share in 2017.

\footnotetext{
${ }^{6}$ There are a few ways to demonstrate this. 1) controlling for constituency dummy variables (i.e. all possible constituency variation) only reduces the individual-level EU referendum Labour/Conservative marginal effect from 39.6 percentage points to 38.1 percentage points, 2) multinomial models of vote choice containing just aggregate level measures of cosmopolitan industries have a pseudo r-squared of 0.005 , compared with 0.098 for just the individual level EU referendum effect and 3) after controlling for 2015 vote and individual EU referendum choice, aggregate cosmopolitan industries do not significantly predict Labour versus Conservative voting. Further details of the models are available on request. We do not dismiss the role of geographic factors entirely (or consider this a full exploration of them), but merely recognize that their effects do not rival individual level EU referendum vote choice.
} 
We can see the large but varying importance of Brexit in Table 2, which shows how Labour and Conservative recruitment of Leave or Remain voters occurred at different stages. The percentages in the table present the proportion of 2017 Labour and Conservative voters (respectively) who were Leave voters in 2016 (where the dominator is Remain and Leave voters), broken down by the timing of their switching. The table shows that both Labour and the Conservatives' vote recruitment was heavily polarized around referendum vote choice prior to the campaign, with $90 \%$ of Conservative recruits voting Leave (excluding non-voters) compared with $30 \%$ of Labour recruits. However, during the campaign, Labour's recruitment was much more evenly divided between Leave and Remain voters (49\% Leave). Labour was also more successful at winning back Leave leaning voters it had lost prior to the campaign.

\begin{tabular}{lrr}
\hline & \multicolumn{2}{c}{ 2017 Vote } \\
Recruitment timing & Labour & Conservative \\
\hline Loyal & 30 & 66 \\
Returners & 41 & 55 \\
Pre-campaign & & \\
recruits & 29 & 90 \\
Campaign recruits & 49 & 84 \\
\hline
\end{tabular}

Table 2 Labour and Conservative 2017 voters percentage voting Leave broken down by time of recruitment (excluding don't knows and non-voters). Each cell shows the percentage Leave vote for respondents in that cell.

The most important group of voters to understand in this regard are those who voted for UKIP in 2015. Prior to the referendum and election there was some debate about whether a UKIP collapse would primarily benefit the Conservative party (Evans and Mellon 2016) or whether the vote would split more evenly towards the major parties in line with UKIP's more diverse long term origins (Ford and Goodwin 2016). In fact, the UKIP vote moved considerably more heavily towards the Conservatives than even the most extreme projections. Mellon and Evans (2016) calculated $45 \%$ of 2014 UKIP intenders had the Conservatives as a second preference. In fact, 73\% of 2015 UKIP 
defectors ended up voting for the Conservatives (57\% of all 2015 UKIP voters). ${ }^{7}$ These figures denote a considerable success for the Conservative strategy, albeit offset, by different Labour gains.

UKIP voters have long been concerned about immigration and linked this concern to the European Union (Ford and Goodwin 2014; Evans and Mellon 2016; Evans and Mellon 2017b). Key for the parties' ratings is not just which party cares most about the issue of immigration, but which party can successfully deliver (Green and Hobolt 2008; Green and Jennings 2017). The Conservative Party used to be most strongly rated on immigration (Green 2011) but with UKIP's rise, the lead of the Conservative party on immigration diminished (Goodwin and Milazzo 2015).

The BESIP survey asked respondents their views about which party would try to reduce immigration if elected, and which party would be successful. Figure 6 shows that prior to the 2015 General Election (wave 4), voters perceived UKIP would be far more likely to actually reduce immigration if they gained power, compared with either the Conservatives or Labour. UKIP held a 25 percentage point lead over the Conservatives. By the start of the campaign (wave 11), however, UKIP held only a 4 percentage point lead over the Conservatives in perceptions of its ability to reduce immigration. We can presume voters perceived that membership of the European Union meant the Conservative party could not credibly commit to reducing immigration. However, with that barrier removed by the vote to leave the EU and the Conservatives' adoption of a hard Brexit position, the immigration competence gap between UKIP and the Conservatives shrank dramatically.

\footnotetext{
${ }^{7}$ For comparability with the Mellon and Evans (2016) these figures are for the whole of Great Britain rather than just England and Wales as the rest of the article displays.
} 


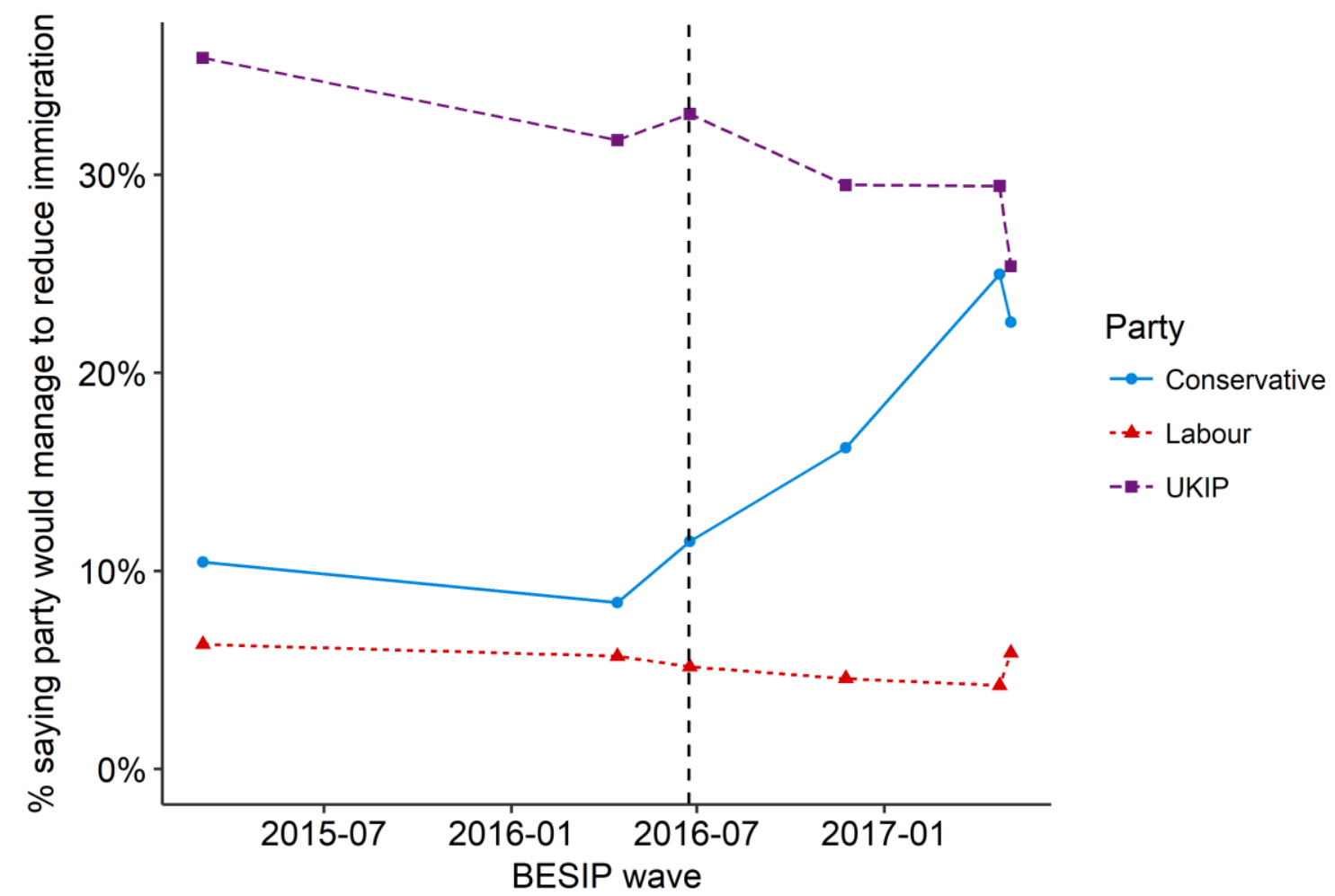

Figure 6 Voters' perceptions of parties' ability to reduce immigration. Based on the question: 'Would any of the following political parties be successful - if elected - in reducing the level of immigration?' where respondents can tick all parties that they think would reduce the level of immigration

The narrowing gap between Conservative and UKIP credibility on immigration is important. 2015 UKIP voters were 36 percentage points more likely to switch to the Conservatives in 2017 if they believe the Conservatives were capable of reducing immigration (Figure 7). Competence on immigration was therefore a key part of the story of the Conservatives' consolidation of the Leave vote. Brexit was a shock that altered voters' perceptions of the Conservatives on immigration, just as other major shocks cause parties to lose and gain favourability on issues (Green and Jennings 2017). 


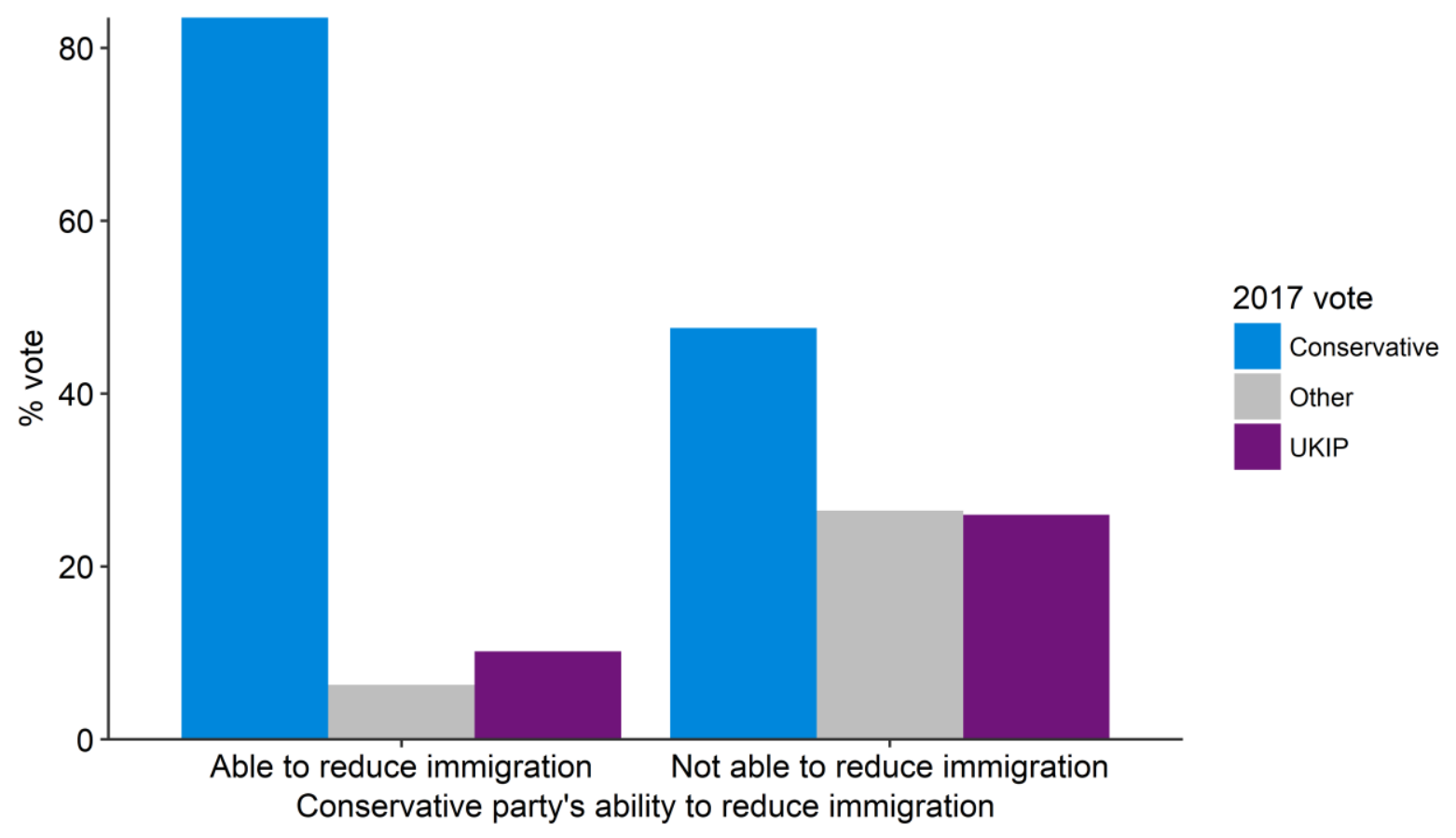

Figure 72017 vote choices of 2015 UKIP voters by whether they think the Conservative are able to reduce immigration (measured in the 2017 campaign). Based on the question: 'Would any of the following political parties be successful - if elected - in reducing the level of immigration?'

\section{Conclusions}

The story of the 2017 election that emerges from our analysis is one of a sequence of switching. The EU referendum removed the main obstacle to a credible Conservative policy on immigration. As UKIP supporters recognised this change in credibility, they switched to the Conservatives in large numbers. Indeed the Conservatives recruited Leave voters from all 2015 party origins. At the same time the Corbyn-led Labour party absorbed a large portion of the 2015 Green Remain vote but before the campaign had lost a lot of former voters to the Liberal Democrats and the 'don't know' category. In the campaign, however, Brexit structured the vote flows much less strongly. Instead the main story was that Labour managed to claim voters from both the Leave and Remain side in substantial numbers but particularly among respondents intending to vote Liberal Democrat or who said 'don't know' prior to the General Election campaign. The net result of the campaign was to increase the Labour share without substantially increasing or decreasing the Brexit split in 
Labour/Conservative voting. A major campaign factor was the change in leader evaluations and their relationship to vote switching. 2017 was both a 'Brexit election' and a leadership campaign.

Previous work has shown some apparently stable elections were actually volatile below the surface and that the underlying volatility was able to have dramatic results when voters all moved in the same direction at the same time (Mellon 2016). This paper shows the same is true of British election campaigns. A fairly similar number of voters changed their minds between the start and end of the 2017 campaign and campaigns over the last few election cycles. However, in previous cycles this switching largely cancelled out, leaving the impression that campaigns are irrelevant to British election outcomes. The 2017 election shows that when these flows do not cancel out, the level of volatility is sufficient to create dramatic aggregate changes.

The 2017 election was unusual in delivering a large increase in the two-party vote share after a long run of party system fragmentation. However, there is little indication of a return to the two-party politics of the 1960s, which saw stable attachments built around long running identities and class linkages (Fieldhouse et al. 2018). In 2017 the main factors we identified driving the two-party vote are the strong effect of EU referendum vote choice on 2017 party support, the Conservatives' perceived competence in dealing with immigration as a driver of some of that effect, and the perceptions of party leaders during the campaign. While the EU referendum is likely to continue to be a major source of division within British politics, there is no guarantee voters will express this division in the same way they did in 2017. Competence and leadership evaluations are not stable divides in the same way as class and longstanding partisan identity, and there are other parties vying for votes on both the Leave and Remain sides. Whereas the vote for the two major parties increased substantially in 2017, the same is not true for party identity. The proportion of BESIP survey respondents identifying with either Labour or the Conservatives was remarkably stable between 
2015 and 2017, whilst the proportion of respondents who did not identify with any party increased. ${ }^{8}$ If Theresa May cannot deliver control of immigration or Jeremy Corbyn loses the confidence of his new voters, the electorate has demonstrated a clear willingness to change their minds in British elections.

${ }^{8} 28 \%$ identified with the Conservatives in 2015 , compared to $26 \%$ in $2017.26 \%$ identified with Labour in 2015 , compared to $27 \%$ in $2017.31 \%$ did not identify with a party in 2015 , compared to $35 \%$ in 2017. 


\section{References}

Erikson, Robert S., and Christopher Wlezien. 2012. The Timeline of Presidential Elections: How Campaigns Do (and Do Not) Matter. University of Chicago Press.

Evans, Geoffrey, and Jonathan Mellon. 2015. "The Political Popularity Contest." Significance 12 (2): 8-10. doi:10.1111/j.1740-9713.2015.00809.x.

-- - 2016. "Working Class Votes and Conservative Losses: Solving the UKIP Puzzle." Parliamentary Affairs 69 (2). Oxford University Press: 464-79. doi:10.1093/pa/gsv005.

- - . 2017a. "Liberal-Authoritarianism and Britain's New Cleavage Structure: Dimensional and Demographic Correlates of 2015 and 2017 British Voting." American Political Science Association Annual Conference 2017.

- - . 2017b. "The Accidental Dimension: Immigration, Euroscepticism and the Rise and Fall of UKIP." Working Paper, 1-35.

Fieldhouse, Edward, Jane Green, Geoffrey Evans, Jonathan Mellon, Christopher Prosser, Hermann Schmitt, and Cees van der Eijk. 2018. The Volatile Voter: Political Shocks and the Fragmentation of the British Party System. Oxford University Press.

Fieldhouse, Edward, Jane Green, Geoffrey Evans, Hermann Schmitt, Cees van der Eijk, Jonathan Mellon, and Christopher Prosser. 2017. "British Election Study Panel 2014-2018." doi:10.15127/1.293723.

Finkel, Steven E. 1993. "Reexamining the 'Minimal Effects' Model in Recent Presidential Campaigns." The Journal of Politics 55 (1): 1-21.

Ford, Robert, and Matthew J Goodwin. 2014. Revolt on the Right: Explaining Support for the Radical Right in Britain. Taylor \& Francis.

- - . 2016. "Different Class? UKIP's Social Base and Political Impact: A Reply to Evans and Mellon." Parliamentary Affairs 69 (2): 480-91. doi:10.1093/pa/gsv005.

Freedman, Des. 2017. "Corbyn Framed and Unframed." In The Corbyn Effect, edited by Mark Perryman, 96-111. Lawrence and Wishart.

Goodwin, Matthew, and Caitlin Milazzo. 2015. UKIP: Inside the Campaign to Redraw the Map of British Politics. Oxford University Press.

Green, Jane. 2011. "A Test of Core Vote Theories: The British Conservatives, 1997-2005." British Journal of Political Science 41 (4): 735-64. doi:10.1017/S0007123411000111.

Green, Jane, and Sara B. Hobolt. 2008. "Owning the Issue Agenda: Party Strategies and Vote Choices in British Elections." Electoral Studies 27 (3): 460-76. doi:10.1016/j.electstud.2008.02.003.

Green, Jane, and Will Jennings. 2017. The Politics of Competence: Parties, Public Opinion and Voters. Cambridge University Press.

Green, Jane, and Christopher Prosser. 2016. "Party System Fragmentation and Single-Party Government: The British General Election of 2015." West European Politics 39 (6): 1299-1310. doi:10.1080/01402382.2016.1173335.

Heath, Oliver, and Matthew Goodwin. 2017. "The 2017 General Election, Brexit and the Return to 
Two-Party Politics: An Aggregate-Level Analysis of the Result." Political Quarterly 88 (3): 34558. doi:10.1111/1467-923X.12405.

Hutton, Robert. 2017. "General Election 2017: What We've Learned So Far." Bloomberg. https://www.bloomberg.com/news/articles/2017-05-19/general-election-2017-what-we-velearned-so-far.

Ipsos MORI. 2017. "How the Voters Voted in the 2017 Election How Britain Voted by Gender Overall Men and Women Had Similar Voting Patterns."

Iyengar, Shanto, and Adam Simon. 2000. "New Perspectives and Evidence on Political Communication and Campaign Effects." Annual Review of Psychology 12 (8): 727-32. doi:10.1177/0741713604268894.

Jennings, Will, and Gerry Stoker. 2017. "Tilting Towards the Cosmopolitan Axis? Political Change in England and the 2017 General Election." Political Quarterly 88 (3): 359-69. doi:10.1111/1467923X.12403.

Massie, Alex. 2015. "Death of a Political Party: Jeremy Corbyn Has Killed Labour." Spectator.

Mckibbin, Ross. 2017. "In the Shadow of the Referendums." Political Quarterly 88 (3): 382-85. doi:10.1111/1467-923X.12398.

Mellon, Jonathan. 2016. "Party Attachment in Great Britain: Five Decades of Dealignment."

Mellon, Jonathan, and Geoffrey Evans. 2016. "Class, Electoral Geography and the Future of UKIP: Labour's Secret Weapon?" Parliamentary Affairs 69 (2): 492-98. doi:10.1093/pa/gsv013.

Roberts, Andrew. 2016. "A Great Realignment Is Coming. We Cannot Assume Labour Will Survive It." The Telegraph.

Rudiger, Schmitt-Beck, and David M Farrell. 2002. "Do Political Campaigns Matter? Yes, but It Depends." In Do Political Campaigns Matter?: Campaign Effects in Elections and Referendums, edited by David M Farrell and Schmitt-Beck Rudiger. Routledge.

Snowdon, Kathryn. 2017. "General Election 2017: 10 Forgotten Issues During The Campaign." HuffPost UK. http://www.huffingtonpost.co.uk/entry/general-election-2017-10-forgottenissues-during-the-campaign_uk_593688d7e4b013c4816ad4ef.

Walker, Peter. 2017. "Labour Could Slump to below 150 MPs, Fabian Society Warns." The Guardian. 
Supplementary material: Transition Tables for Remain and Leave voters before and during the campaign

This appendix contains the row percentages of switching for 2015 (wave 6) to the pre-campaign wave (wave 11) and the 2017 campaign (waves 11 to 13).

\begin{tabular}{|c|c|c|c|c|c|c|c|c|c|}
\hline \multirow[t]{2}{*}{ W6W11 } & \multicolumn{9}{|c|}{ Leave } \\
\hline & Conservative & Labour & Lib Dem & Plaid & UKIP & Green & Other & Don't know & Total \\
\hline Conservative & 87 & 2 & 1 & 0 & 3 & 0 & 0 & 7 & 100 \\
\hline Labour & 16 & 51 & 2 & 0 & 7 & 2 & 0 & 21 & 100 \\
\hline Lib Dem & 29 & 12 & 32 & 0 & 5 & 1 & 0 & 21 & 100 \\
\hline Plaid & 32 & 15 & 0 & 37 & 0 & 0 & 16 & 0 & 100 \\
\hline UKIP & 47 & 4 & 1 & 0 & 34 & 1 & 1 & 12 & 100 \\
\hline Green & 20 & 18 & 0 & 0 & 3 & 18 & 0 & 40 & 100 \\
\hline BNP & 30 & 70 & 0 & 0 & 0 & 0 & 0 & 0 & 100 \\
\hline Other & 22 & 16 & 4 & 0 & 4 & 3 & 13 & 37 & 100 \\
\hline
\end{tabular}

Table S1 Transition table between 2015 post-election and 2017 pre-campaign BESIP waves for Leave voters. Rows are origins and columns destination. Row percentages shown.

\begin{tabular}{|c|c|c|c|c|c|c|c|c|c|}
\hline \multirow[t]{2}{*}{ W6W11 } & \multicolumn{9}{|c|}{ Remain } \\
\hline & Conservative & Labour & Lib Dem & Plaid & UKIP & Green & Other & Don't know & Total \\
\hline Conservative & 71 & 4 & 11 & 0 & 0 & 2 & 0 & 12 & 100 \\
\hline Labour & 5 & 69 & 13 & 0 & 0 & 2 & 1 & 11 & 100 \\
\hline Lib Dem & 5 & 18 & 60 & 0 & 0 & 2 & 1 & 12 & 10 \\
\hline Plaid & 4 & 27 & 3 & 62 & 0 & 0 & 0 & 2 & 100 \\
\hline UKIP & 39 & 2 & 10 & 1 & 14 & 6 & 2 & 25 & 100 \\
\hline Green & 1 & 42 & 15 & 0 & 0 & 32 & 0 & 10 & 100 \\
\hline Other & 19 & 10 & 31 & 0 & 0 & 7 & 14 & 19 & 100 \\
\hline
\end{tabular}

Table S2 Transition table between 2015 post-election and 2017 pre-campaign BESIP waves for Remain voters. Rows are origins and columns destination. Row percentages shown.

\begin{tabular}{|c|c|c|c|c|c|c|c|c|}
\hline \multirow[t]{2}{*}{ W11W13 } & \multicolumn{8}{|c|}{ Leave } \\
\hline & Conservative & Labour & Lib Dem & Plaid & UKIP & Green & Other & Total \\
\hline \multicolumn{9}{|l|}{ I would not } \\
\hline vote & 21 & 72 & 2 & 0 & 3 & 2 & 0 & 100 \\
\hline Conservative & 90 & 6 & 1 & 0 & 2 & 0 & 1 & 100 \\
\hline Labour & 5 & 93 & 2 & 0 & 0 & 0 & 0 & 100 \\
\hline Lib Dem & 16 & 19 & 58 & 0 & 0 & 5 & 1 & 100 \\
\hline Plaid & 28 & 14 & 0 & 53 & 0 & 0 & 6 & 100 \\
\hline UKIP & 36 & 21 & 1 & 0 & 37 & 3 & 2 & 100 \\
\hline Green & 8 & 22 & 11 & 0 & 4 & 54 & 1 & 100 \\
\hline Other & 9 & 16 & 0 & 4 & 27 & 4 & 40 & 100 \\
\hline Don't know & 27 & 52 & 10 & 0 & 5 & 2 & 3 & 100 \\
\hline
\end{tabular}


Table S3 Transition table between 2017 pre-campaign and post-election BESIP waves for Leave voters. Rows are origins and columns destination. Row percentages shown.

\begin{tabular}{|c|c|c|c|c|c|c|c|c|}
\hline \multirow[t]{2}{*}{ W11W13 } & \multicolumn{8}{|c|}{ Remain } \\
\hline & Conservative & Labour & Lib Dem & Plaid & UKIP & Green & Other & Total \\
\hline I would not & & & & & & & & \\
\hline vote & 29 & 64 & 2 & 0 & 0 & 5 & 0 & 100 \\
\hline Conservative & 83 & 11 & 5 & 0 & 0 & 1 & 1 & 100 \\
\hline Labour & 1 & 94 & 4 & 0 & 0 & 0 & 0 & 100 \\
\hline Lib Dem & 4 & 32 & 62 & 0 & 0 & 2 & 1 & 100 \\
\hline Plaid & 0 & 18 & 1 & 82 & 0 & 0 & 0 & 100 \\
\hline UKIP & 36 & 14 & 0 & 0 & 44 & 7 & 0 & 100 \\
\hline Green & 4 & 47 & 14 & 0 & 0 & 33 & 2 & 100 \\
\hline Other & 24 & 32 & 17 & 0 & 0 & 7 & 21 & 100 \\
\hline Don't know & 16 & 57 & 15 & 0 & 1 & 7 & 3 & 100 \\
\hline
\end{tabular}

Table S4 Transition table between 2017 pre-campaign and post-election BESIP waves for Remain voters. Rows are origins and columns destination. Row percentages shown.

\begin{tabular}{ccccccccccc}
\hline Wave & Conservative & Labour & Lib Dem & Plaid & UKIP & Green & Other & DK & Total \\
\hline \multirow{2}{*}{6} & $\mathrm{n}$ & 2349 & 1880 & 475 & 39 & 821 & 233 & 53 & & 5849 \\
& $\%$ & 40 & 32 & 8 & 1 & 14 & 4 & 1 & & 100 \\
\hline \multirow{2}{*}{7} & $\mathrm{n}$ & 1645 & 1672 & 270 & 33 & 917 & 191 & 59 & 1413 & 6198 \\
& $\%$ & 27 & 27 & 4 & 1 & 15 & 3 & 1 & 23 & 100 \\
\hline \multirow{2}{*}{8} & $\mathrm{n}$ & 1564 & 1627 & 295 & 38 & 997 & 211 & 31 & 1445 & 6208 \\
& $\%$ & 25 & 26 & 5 & 1 & 16 & 3 & 1 & 23 & 100 \\
\hline \multirow{2}{*}{9} & $\mathrm{n}$ & 1569 & 1389 & 374 & 28 & 791 & 192 & 59 & 1811 & 6213 \\
& $\%$ & 25 & 22 & 6 & 0 & 13 & 3 & 1 & 29 & 100 \\
\hline \multirow{2}{*}{10} & $\mathrm{n}$ & 1939 & 1372 & 415 & 28 & 663 & 187 & 34 & 1532 & 6170 \\
& $\%$ & 31 & 22 & 7 & 0 & 11 & 3 & 1 & 25 & 100 \\
\hline \multirow{2}{*}{11} & $\mathrm{n}$ & 2499 & 1514 & 543 & 23 & 366 & 172 & 40 & 1008 & 6165 \\
& $\%$ & 41 & 25 & 9 & 0 & 6 & 3 & 1 & 16 & 100 \\
\hline \multirow{2}{*}{12} & $\mathrm{n}$ & 2476 & 1856 & 500 & 27 & 254 & 154 & 51 & 832 & 6150 \\
& $\%$ & 40 & 30 & 8 & 0 & 4 & 3 & 1 & 14 & 100 \\
\hline \multirow{2}{*}{13} & $\mathrm{n}$ & 2517 & 2406 & 575 & 27 & 192 & 129 & 77 & & 5922 \\
& $\%$ & 43 & 41 & 10 & 0 & 3 & 2 & 1 & & 100 \\
\hline
\end{tabular}

Table S5 Weighted cell counts and percentages of vote intention/choice (excluding non-voters and those who do intend to vote and those who stated don't know in election waves for England and Wales only) for each wave for respondents with valid wave 6-13 panel weights (wt_new_W6_W13 in the BESIP data). Total unweighted $n$ for wave 6-13 panel is 6,406.

\begin{tabular}{lcc}
\hline EU Ref vote & $\mathrm{n}$ & $\%$ \\
\hline Remain & 2533 & 40 \\
Leave & 2934 & 46
\end{tabular}




\begin{tabular}{lcc} 
DK & 74 & 1 \\
DNV & 865 & 14 \\
\hline Total & 6,406 & 100 \\
\hline
\end{tabular}

Table S6 Weighted cell counts and percentages of EU referendum choice (for England and Wales only) for each wave for respondents with valid wave 6-13 panel weights (wt_new_W6_W13 in the BESIP data). Total unweighted $n$ for wave 6-13 panel is 6,406. 